\title{
Enhanced Soil Chemical Properties and Rice Yield in Acid Sulphate Soil by Application of Rice Straw
}

\author{
Siti Nurzakiah, Nurita and Linda Indrayati \\ Indonesian Research Institute for Swampland Agriculture, Jl. Kebun Karet, Loktabat, Banjarbaru PO. Box \\ 31 Kalimantan Selatan, Indonesia. Phone/Fax. (0511) 4772534 - 4773034, \\ e-mail: zakiah_balittra@yahoo.co.id
}

Received 15 May 2009 / accepted 15 August 2011

\begin{abstract}
Swampland development such as acid sulphate soil for agricultural cultivation has various problem, including high soil acidity, fluctuated and unpredictable water flooding and the presence of toxic elements such as Fe which resulting in low crop yields. The research was conducted at the experimental station Belandean, Barito Kuala regency in dry season 2007. The objective of research was to study the effect of rice straw on the dynamic of soil $\mathrm{pH}$, the concentration of iron and sulphate and yield on tidal land acid sulphate soil at two different water inlet channel. This research was designed in RCBD (Randomized Completely Block Design) with five treatments (0, 2.5, 5.0, 7.5 and $10 \mathrm{Mg} \mathrm{ha}^{-1}$ ) and four replications. Dolomite as much as $1 \mathrm{Mg} \mathrm{ha}^{-1}$ was also applied. This research was divided into two sub-units experiment i.e. two conditions of different water inlet channel. The first water channels were placed with limestone and the second inlet was planted with Eleocharis dulcis. The results showed that (i) rice straw application did not affect the dynamic of soil $\mathrm{pH}$, concentration of iron and sulphate, and (ii) the highest yield was obtained with $7.5 \mathrm{Mg} \mathrm{ha}^{-1}$ of rice straw.
\end{abstract}

Keywords: Acid sulphate soil, rice straw, rice yield, soil chemical properties

\section{INTRODUCTION}

Swampland has an important role in agriculture development. The development of acid sulphate soils have several constraints including high soil acidity. Oxidation of phyrite compound increases soil acidity and the solubility of $\mathrm{Fe}^{2+}$. Fluctuated and unpredictable water flooding causes low water quality. Improving the water quality can be carried by flowing water through the biofilter of Eleocharis dulcis and it could increase the $\mathrm{pH}$ from 0.14 to 0.25 units and decrease concentration of $\mathrm{Fe}$ (6-27 $\left.\mathrm{mg} \mathrm{kg}{ }^{-1}\right)$ and $\mathrm{SO}_{4}\left(30-75 \mathrm{mg} \mathrm{kg}^{-1}\right)$ (Jumberi et al. 2003). E. dulcis can be applied on both in tertiary channel and quaternary channels.

Soil acidity can be reduced by applying ameliorant such as organic matter and lime. Organic mater is a source of nutrient that have ability to chelate heavy metals that poisoned plants. Rice straw contains several nutrients such as N, P, K, and S (Makarim et al. 2007). Dobermann and Fairhurst (2000) stated that every $1,000 \mathrm{~kg}$ of rice straw that returning contained approximately $5-8 \mathrm{~kg}$ $\mathrm{N} \mathrm{ha}^{-1}$, 0.7-1.2 $\mathrm{kg} \mathrm{P} \mathrm{ha}^{-1}$ and 12-17 $\mathrm{kg} \mathrm{K} \mathrm{ha}^{-1}$.

J Trop Soils, Vol. 17, No. 1, 2012: 31-36 ISSN 0852-257X
Limestone also reduces the concentration of toxic ions such as $\mathrm{H}^{+}, \mathrm{Al}^{3+}, \mathrm{Fe}^{2+}$ and $\mathrm{SO}_{4}^{2-}$.

Ca element contained in the lime plays a key role as an essential nutrient in plant and participates in root and stem elongation (White and Broadley 2003). It is related to its role as a regulator of growth and development (Hepler 2005). Lime has the ability to neutralize soil acidity so that the macro and micro nutrient availability will be increase. Therefore nutrient availability in acidic sulfate soil is low to very low, knowledge of nutrient deficiency is important factor when the reclamation and management practices are performed in acid sulphate soil (Jintaridth et al. 2006).

Result of research showed that $1.5 \mathrm{Mg} \mathrm{ha}^{-1}$ $\mathrm{CaCO}_{3}$ increased rice yield $30 \%$ on acid sulphate soils type B Unit Tatas, Central Kalimantan. However, application of $2.0 \mathrm{Mg} \mathrm{ha}^{-1} \mathrm{CaCO}_{3}$, increased rice yield by $20 \%$ on acid sulphate soils type C Barambai, South Kalimantan (Noor 2004). Combination of rice straw $\left(5.0 \mathrm{Mg} \mathrm{ha}^{-1}\right)$ with lime (3.5 $\mathrm{Mg} \mathrm{ha}^{-1}$ ) increased soil $\mathrm{pH}$ from 4.32 to 4.50 , decrease the concentration of $\mathrm{Fe}^{2+}$ and $\mathrm{SO}_{4}{ }^{2-}$, as to $22.9 \%$ and $11.7 \%$, and increase the yield of paddy (variety Margasari) 59.96\% compared with controls (Hairani et al. 2006). Results of these studies indicated that proper management of land (utilization 
of materials such as rice straw ameliorant and lime and water management, combined with the use of biofilter) could increase productivity of soil and plant.

The objctive of the present study was to study the effect of rice straw on the dynamic of soil $\mathrm{pH}$, the concentration of iron and sulphate and the rice yield on tidal land acid sulphate soil at two different water inlet channel.

\section{MATERIALS AND METHODS}

\section{Study Site}

This research was conducted on acid sulphate soils type B in the dry season in 2007 . This research was a long-term experiment that began in dry season 2003 in experimental station Belandean, Barito Kuala, South Kalimantan.

\section{Exprimental Set up}

The plot experiment was a $6 \times 6 \mathrm{~m}$. Ameliorant that used was rice straw with five dosages: $0,2.5$, $5,7.5 ; 10\left(\mathrm{Mg} \mathrm{ha}^{-1}\right)$. Treatments were arranged in RCBD with four replications so all treatments were 20 units. Lime, $1 \mathrm{Mg} \mathrm{ha}^{-1}$ was also applied. Irrigation system on experimental plots set up by the system of water flow in one direction by using automatic door. Water from the tertiary channel came through the door into the water inlet, and then flowed into the plot of paddy field. The experiment was divided into two sub-units of the experiment, two conditions of water inlet channel with channel dimensions (50 $\mathrm{m}$ length, $1 \mathrm{~m}$ width and $0.8 \mathrm{~m}$ depth). The first water channels was placed with limestone given as much as $300 \mathrm{~kg}$ of lime (6 sacks), and placed separately (3 parts), respectively - each was 2 sack which equals to $100 \mathrm{~kg}$. The second water channels was planted as much as $2 \%$ of land area and planted simultaneously with rice seedlings.

\section{Land Preparation and Plantation}

Land was prepared by cutting the weed and cultivating with trowel (traditional tool). The spread straw and lime were spread on land that has been prepared, before scattered, straw should be mashed with chopped, then according to the dosage, each straw was spread into the plot before planting. Rice was planted when seedlings were 25 days old with a distance of a $20 \times 20 \mathrm{~cm}$ (Batanghari varieties). Urea fertilizer was applied twice that were at oneweek-old and one-month old plants with total 100 $\mathrm{kg} \mathrm{ha}^{-1}$ while $\mathrm{KCl}$ fertilizer dosage of $100 \mathrm{~kg} \mathrm{ha}^{-1}$ and SP-36 fertilizer with a dosage of $200 \mathrm{~kg} \mathrm{ha}^{-1}$ given during one-week-old plants. Observation of plant performance was iron scoring (IRRI 1996) at rice severed from environmental stress and the grain weight.

\section{Soil Sampling and Analysis}

Soil samplings were conducted twice, depend on certain condition of soil chemical properties that have known based on previous research. Soil parameters that observed were $\mathrm{pH}\left(\mathrm{H}_{2} \mathrm{O}\right.$ extract of 1: 2.5 - Electrodes Glass), $\mathrm{Fe}^{2+}$ (extract $\mathrm{NH}_{4} \mathrm{OAc}$ $1 \mathrm{~N} \mathrm{pH} 4.8$ - AAS ) and $\mathrm{SO}_{4}{ }^{2-}\left(\mathrm{H}_{2} \mathrm{O}\right.$ extract Spectrophotometer) (Balai Penelitian Tanah 2005).

\section{Statistical Analysis}

All data were analysed by standard error and drawn with Sigma Plot program by Systat Software Inc.

\section{RESULTS AND DISCUSSION}

\section{Dynamic of Soil $\mathrm{pH}, \mathrm{Fe}^{2+}$ and $\mathrm{SO}_{4}{ }^{2-}$}

\section{Dynamic of soil pH}

Rice straw treatment did not show the differences among the treatments both on observation 5 and 10 WAP both in two different water inlet channel (Figure 1). Organic acids that produced from rice straw decomposition process is dominated by acetic acid that buffer the process of soil $\mathrm{pH}$. Acetic acid is the dominant organic acids formed in the early stages of rice straw decomposition in flooded soil and have an influence on soil acidity (Tadano and Yoshida 1978). According to Huang and Violante (1986) the concentration of acetic acid in the soil solution could reach $265-570 \times 10^{5} \mathrm{M}$. The occurrence buffer during the changing process of soil $\mathrm{pH}$ because of the release of $\mathrm{H}^{+}$ions from soil solvent due process of dissociation of acetic acid carboxyl group. Carboxyl group dissociation that can occur at $\mathrm{pH} 3$ 9 (Tan 1986), so that although straw can cause reductive condition but remains statistically not different on $\mathrm{pH}$ values among treatments.Figure 1 shows a higher $\mathrm{pH}$ value at $10 \mathrm{WAP}$ observation. It was the reaction of dolomite which was slower in release (Kuswandi 1993), Ca and Mg ions were produced from the hydrolysis process of lime sufficient to neutralize soil acidity so that the soil $\mathrm{pH}$ increased. According to Kovaèeviæ and Rastija (2010)_dolomite and calcite are plenty of used to neutralize soil acidity.

Although there was no difference between treatments, but the water inlet with lime treatment, visible increased in soil $\mathrm{pH}$ with increasing doses of 

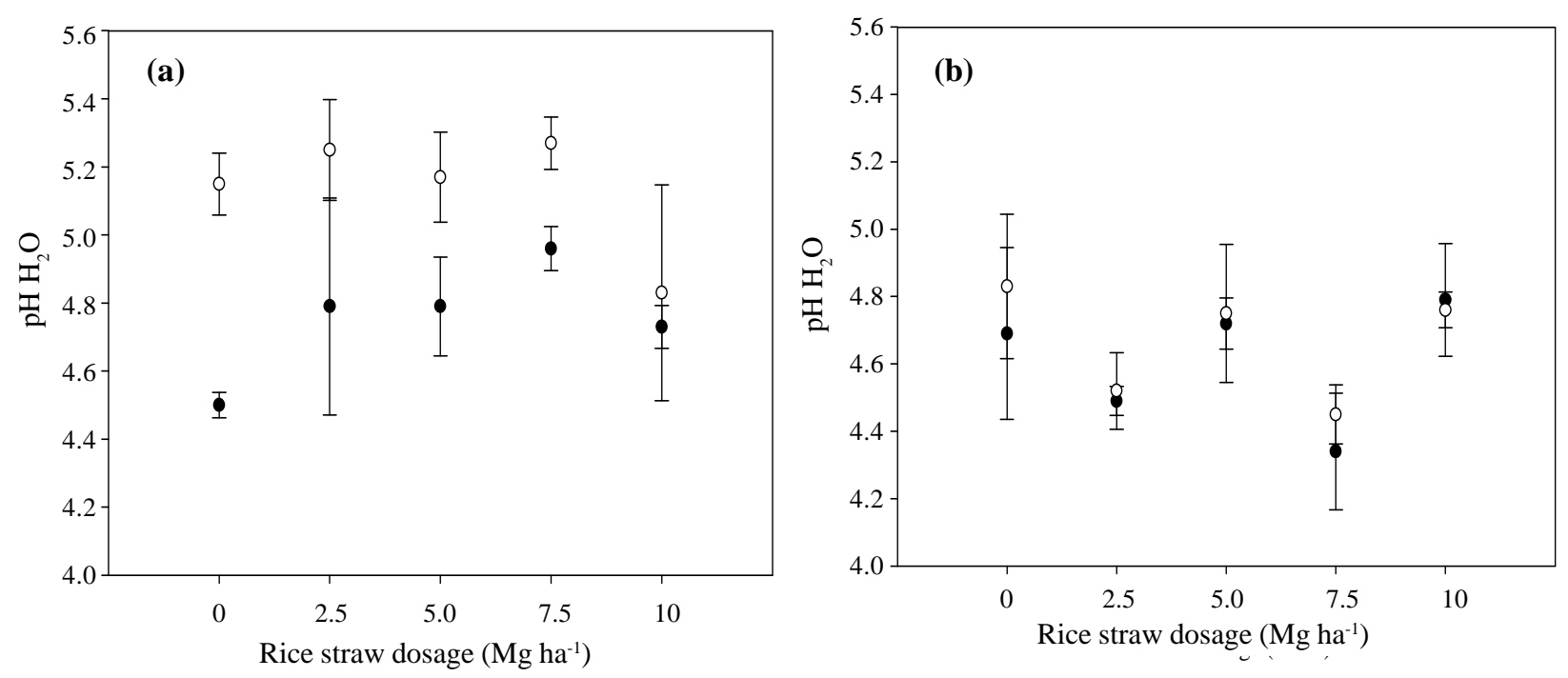

Figure 1. Dynamic of soil $\mathrm{pH}$ as affected by applicaion of ameliorant rice straw on the water inlet with lime treatment (a) and water inlet that planted with $E$ dulcis (b). $\bullet=5$ WAP and $O=10$ WAP.

straw given (0 to $7.5 \mathrm{Mg} \mathrm{ha}^{-1}$ ), this was due to reduction of $\mathrm{Fe}^{3+}$ to $\mathrm{Fe}^{2+}$ by the organic materials that could increase soil $\mathrm{pH}$ and increased the concentration of $\mathrm{Fe}^{2+}$ (Figure 2a) (Konsten et al. 1990),_whereas at straw doses of $10 \mathrm{Mg} \mathrm{ha}^{-1}$ decreasing soil $\mathrm{pH}$ was related with organic acid produced from the decomposition process. Kongchum (2005) reported that rice straw paddy decreased soil $\mathrm{pH}$. Soil $\mathrm{pH}$ values on the water inlet that planted with $E$. dulcis were fluctuated and was in the ranged of 4.3 to 4.8. Unlike to water inlet with lime treatment, soil $\mathrm{pH}$ increased to 5.3. This was related to lime which was technically better than other ameliorant materials in improving the soil $\mathrm{pH}$.

\section{Dynamic of $\mathrm{Fe}^{2+}$ Concentration}

Application of straw with different dosages were not affected the measured concentration of $\mathrm{Fe}^{2+}$ on both inlet water channel (Figure 2). Nevertheless, Straw application tended to increase the concentration of iron because the organic material is an electron donor which causes more reductive atmosphere, resulting in increase concentration of $\mathrm{Fe}^{3+}$ to $\mathrm{Fe}^{2+}$. However treatment of $10 \mathrm{Mg} \mathrm{ha}^{-1}$ (10 WAP) straw showed more lower value in $\mathrm{Fe}^{2+}$ concentration. It shows that if organic material completely decomposed, it will produce humic substances that have a role in lowering the concentration of $\mathrm{Fe}^{2+}$ through chelation (Stevenson 1994). Figure 2 also shows that the concentration of $\mathrm{Fe}^{2+}$ was higher on 5 WAP at both inlet water channel. This is apparently related to soil redox condition. Inundation that supported with availability of organic material will trigger a reduction of $\mathrm{Fe}^{2+}$, increases solubility with the following equation: $\mathrm{Fe}(\mathrm{OH})_{3}+1 / 4 \mathrm{CH}_{2} \mathrm{O}+2 \mathrm{H} \mathrm{Fe}^{2+}+1 / 4 \mathrm{CO}_{2}+11 / 4 \mathrm{H}_{2} \mathrm{O}$ (Groenenberg 1990).

Increasing the concentration of $\mathrm{Fe}^{2+}$ in the acid sulphate soil due to inundation will also be balanced by the increasing concentration of humic in soil solution, so naturally between $\mathrm{Fe}^{2+}$ and material Humic will always balanced, the process will depend on the amount or quality of organic matter (Tan 2003). The solubility of $\mathrm{Fe}^{2+}$ increased in conditions of reductive (5 WAP) but it was not followed by an increase in soil $\mathrm{pH}$ (Figure 1) which was caused by process soil buffers, although there was consumption of $\mathrm{H}^{+}$ions from soil solution, soil $\mathrm{pH}$ did not increase because it simultaneously released $\mathrm{H}^{+}$ions from soil solution which caused dissociation of carboxyl groups. At 10 WAP drained land (before harvest), dry land conditions made oxygen entry easily and caused the oxidation of $\mathrm{Fe}^{2+}$ which resulting in decreasing the concentration of $\mathrm{Fe}^{2+}$. In addition, on treatment of $0 \mathrm{Mg} \mathrm{ha}^{-1}, \mathrm{Fe}^{2+}$ reduction was still occurred, it shows that the influence of inundation was greater than the effect of straw in the process of reduction of $\mathrm{Fe}^{2+}$.

\section{Dynamic of $\mathrm{SO}_{4}{ }^{2-}$ Concentration}

Both in water inlet channel, there was no different in $\mathrm{SO}_{4}{ }^{2-}$ concentration (Figure 3). On observation of 10 WAP, $\mathrm{SO}_{4}{ }^{2-}$ concentration increased. This is related to soil redox conditions during the cultivation where the concentration of $\mathrm{SO}_{4}^{2-}$ increaseing with plant age was related to dry 

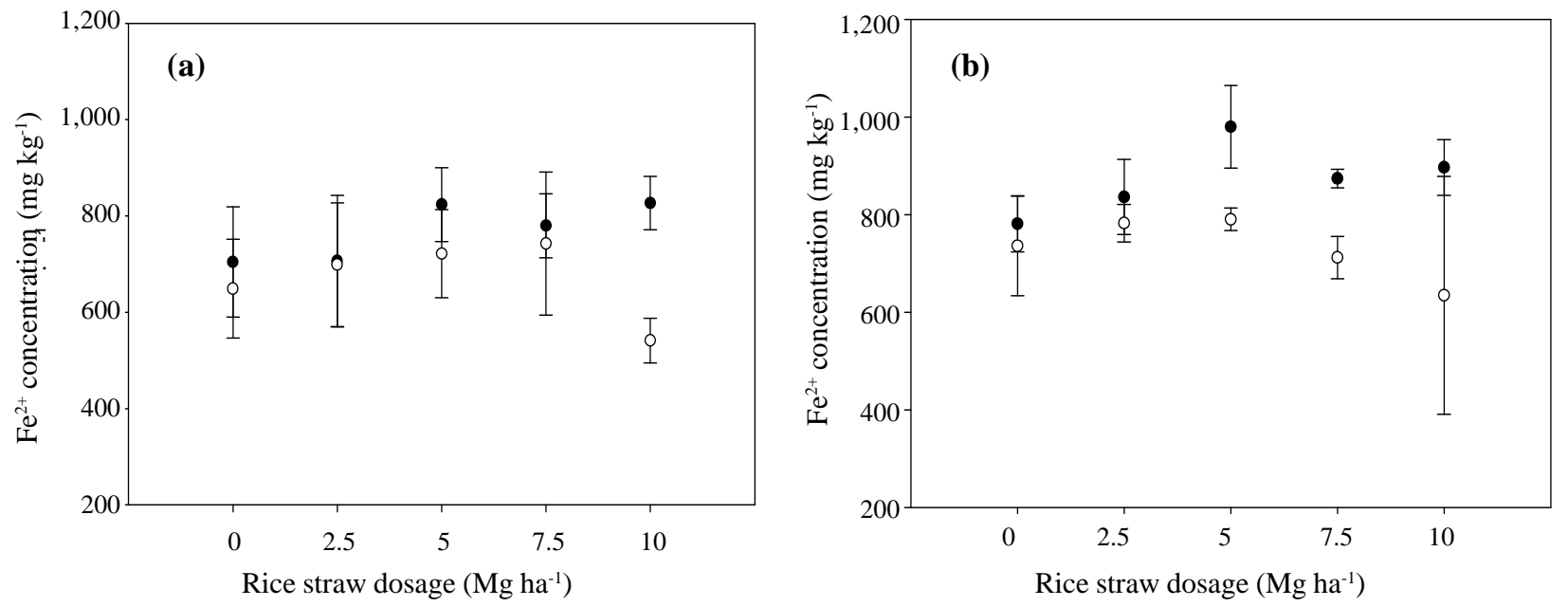

Figure 2. Dynamic of $\mathrm{Fe}^{2+}$ concentration as affected by application of ameliorant rice straw on the water inlet with lime treatment (a) and water inlet that planted with E. dulcis (b). $\bullet=5$ WAP and $O=10$ WAP.

conditions (oxidative) to support the ripening fruit. While the observation at 5 WAP, oxygen availability and sulfate reducing activity of microorganisms was limited so that the $\mathrm{SO}_{4}^{2-}$ concentration decreased. The reduced concentration of $\mathrm{SO}_{4}{ }^{2-}$ also caused by microorganisms that caused metals such as $\mathrm{SO}_{4}^{2-}$ precipitated (Gazsó 2001). The mechanism of micro-organisms to influence toxic elements include the mobilization and immobilization (Gazsó 2001). Immobilization of heavy metals are shown by the formation of precipitation, biosorption and bioaccumulation. One was influencing the $\mathrm{pH}$ of biosorption and bioaccumulation.

Figure 3 also shows the $\mathrm{SO}_{4}{ }^{2-}$ concentration at 10 WAP which was more lower on dosage of $0,2.5$ and $5.0 \mathrm{Mg} \mathrm{ha}^{-1}$ at channel that placed with limestone. It is caused by $\mathrm{Ca}^{2+}$ ions from lime neutralize the ion $\mathrm{SO}_{4}{ }^{2-}$ that forming $\mathrm{CaSO}_{4}$ (gypsum), thereby reduce the activity of sulfate ions. This condition was also supported by the $\mathrm{pH}$ values above 5 (Figure 1) that consequently inhibited the activity of oxidizing bacteria, due to the increased population of other bacteria that could compete in making the various needs of life such as oxygen and others. According to Mills (2002) bacterial substitution occurs with changes in soil $\mathrm{pH}$.

The ability to absorb or neutralize the element of $\mathrm{S}$ caused $\mathrm{SO}_{4}^{2-}$ concentrations were lower in the water inlet channel which was planted by E. dulcis (Figure 3b). Mulyanto et al. (1998) cited by Jumberi et al. (2003), reported that E. dulcis were able to absorb $\mathrm{S}$ element as $4,500 \mathrm{mg} \mathrm{kg}^{-1}$
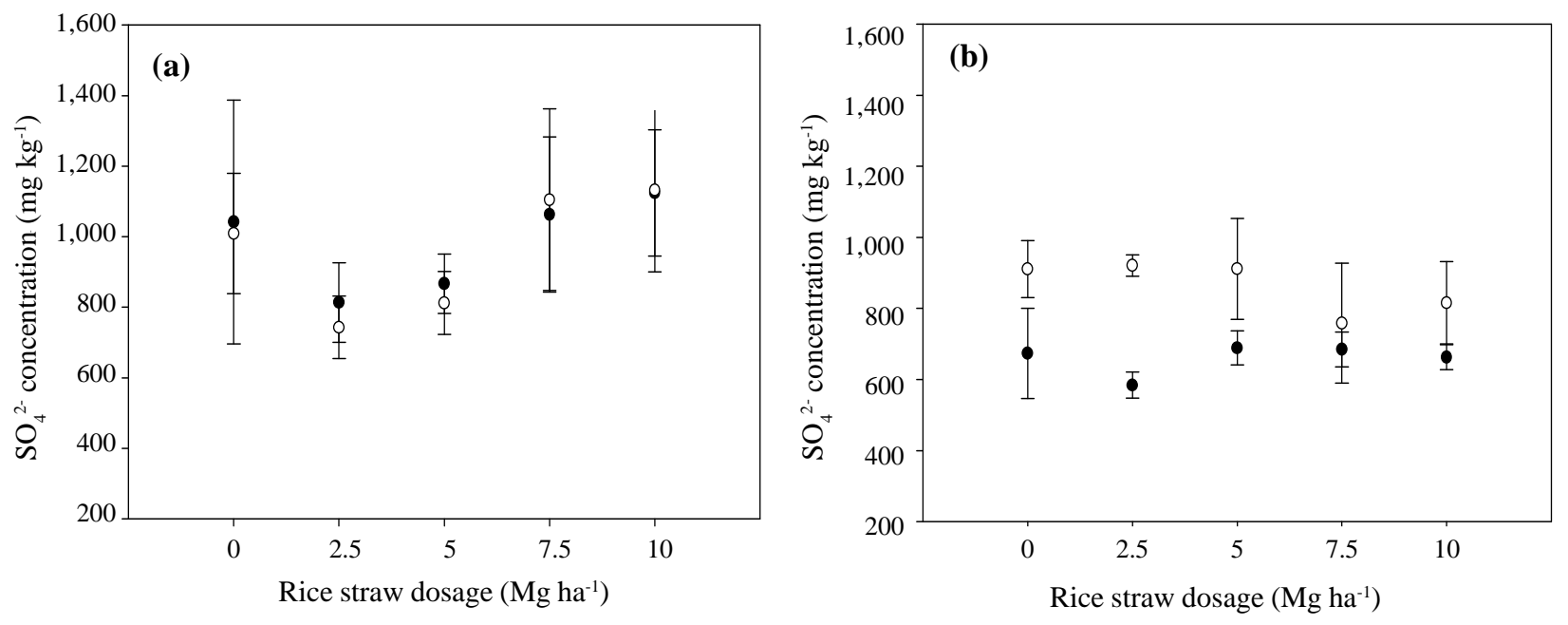

Figure 3. Dynamic of $\mathrm{SO}_{4}{ }^{2-}$ concentration as affected by application of ameliorant rice straw on the water inlet with lime treatment (a) and water inlet that planted with E. dulcis (b). $\bullet=5$ WAP and $0=10$ WAP. 
Table 1. Score of $\mathrm{Fe}^{2+}$ toxicity based on IRRI (1996).

\begin{tabular}{ccccc}
\hline \multirow{2}{*}{$\begin{array}{c}\text { Rice straw } \\
\text { Dosage }\left(\mathrm{Mg} \mathrm{ha}^{-1}\right)\end{array}$} & \multicolumn{2}{c}{ Water inlet with lime } & \multicolumn{2}{c}{$\begin{array}{c}\text { Water inlet that planted with } \\
\text { E. dulcis }\end{array}$} \\
\cline { 2 - 5 } & 5 WAP & 10 WAP & 5 WAP & 10 WAP \\
\hline 0 & 5 & $4-5$ & $4-5$ & $4-5$ \\
2.5 & 4 & 4 & 4 & $3-4$ \\
5.0 & 4 & 4 & $3-4$ & 3 \\
7.5 & $3-4$ & 3 & $2-3$ & 3 \\
10 & $3-4$ & 3 & 2 & $2-3$ \\
\hline
\end{tabular}

Fe-toxicity : 2 = growth and tiller formation is almost normal, reddish brown spots at the end of the old leaf, $3=$ growth and tiller formation is almost normal, older leaves reddish brown or yellow orange, $5=$ growth is slightly inhibited the formation of tillers, leaves many change in color, and $7=$ growth and seedling establishment are largely halted.

\section{Iron Toxicity Score and Grain Yield}

Rice plants on the water inlet channel which was planted by E. dulcis showed better performance than treatment of incoming water channels which were given lime (Table 1). This was related to E. dulcis that had the ability to absorb and neutralize the element of $\mathrm{Fe}^{2+}$ and $\mathrm{SO}_{4}^{2-}$ and might be due to its rooting had rhizosfer microbes, as reported by Suriawira (2003) that plants generally have functioning as a biofilter microbial rhizosfer. This microbes are able to release organic and inorganic materials so it has capability to improve the water quality of from metal pollution like $\mathrm{Fe}^{2+}$ and $\mathrm{SO}_{4}{ }^{2-}$, this had resulted in hazardous metals were not active and was not

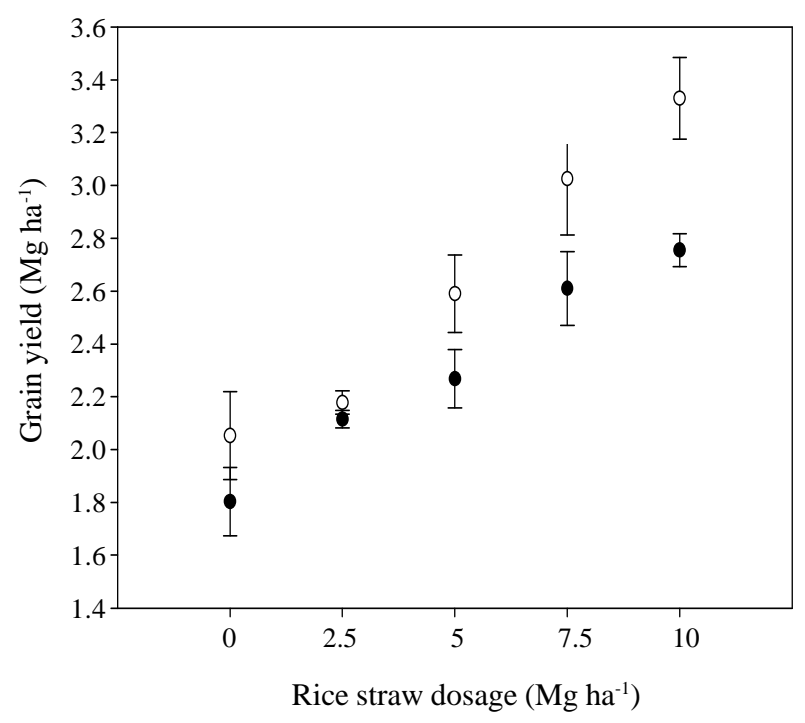

Figure 4. Grain yield as affected by application of rice traw on the two water inlet channels. = water inlet with lime and $O=$ water inlet that planted with E. dulcis. toxic to plants and finally it increased crop yields (Figure 4).

Grain yield increased with increasing dosage of straw (Figure 4). Straw is the major organic material for rice that $\mathrm{N}$ was released during decomposition and its return is slowly (Cho and Kobata 2002). Water inlet channel which was planted by $E$. dulcis had higher yield. Based on statistical analysis, $7.5 \mathrm{Mg} \mathrm{ha}^{-1}$ and $10 \mathrm{Mg} \mathrm{ha}^{-1}$ did not give different yield both in two water inlet channel and increased yield was $45 \%$ (water inlet with lime) and 47.3\% (water inlet that planted with E. dulcis). Application of straw compost improved the availability of nutrients so that the paddy yield also increased (Indriyati and Jumberi 2001; Luu et al. 2001). The addition of organic matter will increase the negative charge that can increase soil cation exchange capacity, there is a correlation between soil organic matter with the CEC (Stevenson 1994). The role of organic matter on nutrient availability in soil can not be separated by the process of mineralization which is the final stage of the decomposition process and in the process of organic matter will be released minerals plant nutrients such as $\mathrm{N}, \mathrm{P}, \mathrm{K}, \mathrm{Ca}, \mathrm{Mg}, \mathrm{S}$, and micro nutrients as well as reduce the solubility of elements in soil solution poisoned by reaction chelation and fixation that can increase nutrient availability and finally increase crop yields.

\section{CONCLUSIONS}

Rice straw application at various dosage levels did not affect the dynamic of soil $\mathrm{pH}$, concentration of iron and sulphate at two different water inlet channel. Dynamic of soil $\mathrm{pH}$ was more influenced by the lime while the concentration of iron and sulphate were more influenced by soil redox 
conditions. Rice straw with a dosage $7.5 \mathrm{Mg} \mathrm{ha}^{-1}$ gave an optimum grain yield with the increase in grain yield in the amount of $45 \%$ to water inlet with lime treatment and $47.3 \%$ to water inlet that planted with E. dulcis.

\section{REFERENCES}

Balai Penelitian Tanah. 2005. Analisis kimia tanah, tanaman, air dan pupuk. Badan Penelitian dan Pengembangan Pertanian. Departemen Pertanian. Bogor. $136 \mathrm{p}$ (in Indonesian).

Cho YS and T Kobata. 2002. N top - dressing and rice straw application for low - input cultivation of transplanted rice in Japan. Korean J Crop Sci 47 (4): 273-278.

Dobermann A and T Fairhurst. 2000. Rice. Nutrient disorders and nutrient management. International Rice Rsearch Insitute. Philippines, 191p.

Gazsó LG. 2001. The key microbial processes in the removal of toxic metals and radionuclides from the environment. CEJOEM 7 (3-4): 178-185.

Groenenberg JE. 1990. Modeling of solute transport and chemical processes in acid sulphate soils. In: Papers Workshop on Acid Sulphate Soils in the Humid Topics, 20-22 November 1990, Bogor, Indonesia, 182-194 pp.

Hairani A, I Noor, M Najib and K Anwar. 2006. Teknologi perbaikan produktivitas lahansulfat masam aktual. In: Laporan Akhir 2006. Balittra. Banjarbaru (in Indonesian).

Hepler PK 2005. Calcium: A central regulator of plant growth and development. The Plant Cell 17: 21422155

Huang PM and A Violante. 1986. Influence of organic acids on crystallization and surface properties of precipitation products of aluminum In: PM Huang and M Schnitzer (eds). Interactions of Soil Minerals with Natural Organics and Microbes. SSSA Special Publication Number 17. Soil Science Society of America, Inc. Madison, Wisconsin, USA, pp. 159-214.

Indrayati L and A Jumberi. 2001. Pengelolaan jerami padi pada pertanaman padi di lahan pasang surut sulfat masam. In: Pengelolaan Tanaman Pangan Lahan Rawa. Badan Penelitian dan Pengembangan Pertanian. Puslitbang Tanaman Pangan. Bogor, pp. 339-346 (in Indonesian).

IRRI [International Rice Research Institute]. 1996. Standard evaluation system for rice. Los Banos. Philippines, $30 \mathrm{p}$.

Jintaridth B, P Limthong, T Inthasothi and C Charoenchamratcheep. 2006. Role and the effectiveness of phospho-microorganisms with rock phosphate. The $18^{\text {th }}$ World Congress of Soil Science Abstract, July 9-15. Philadelphia. Pennsylvania. USA. $681 \mathrm{pp}$.
Jumberi A, M Sarwani and Koesrini. 2003. Komponen teknologi pengelolaan lahan dan tanaman untuk meningkatkan produksi dan efisiensi produksi di lahan sulfat masam. In: Laporan Akhir 2003. Balittra. Banjarbaru (in Indonesian).

Kongchum M. 2005. Effect of Plant Residue and Water management Practices on Soil Redox Chemistry, Methane Emission and Rice Productivity. [Desertation]. Graduate Faculty of the Louisiana State University. USA. 201 p.

Konsten CJM, S Suping, IB Aribawa and IPG WidjajaAdhi. 1990. Chemical processes in acid sulphate soils in Pulau Petak, South and Central Kalimantan. In: Papers Workshop on Acid Sulphate in The Humid Tropics. AARD-LAWOO, Bogor, pp. 109135.

Kovaèeviæ V and M Rastija. 2010. Impacts of liming by dolomit on the maize and barley grain Yields. Poljoprivreda 16 (2): 3-8.

Kuswandi. 1993. Pengapuran tanah pertanian. Yogyakarta. Penerbit Kanisius, 92 p (in Indonesian)

Luu HM, VT Khang and TWatanabe. 2001. Improvement of soil fertility by rice straw manure. Omonrice 9: 68-73.

Makarim A, Sumarno and Suyamto. 2007. Jerami padi. Pengelolaan dan pemanfaatan. Badan Penelitian dan Pengembangan Pertanian. Puslitbang Tanaman Pangan. Bogor, 53 p. (in Indonesian).

Mills C. 2002. The Role of Micro-organisms in Acid Rock Drainage. http://technology.infomine.com/ enviromine/ard/Microorganisms/roleof.htm., Accessed on 27 April 2010.

Noor M. 2004. Lahan rawa. Sifat dan pengelolaan tanah bermasalah sulfat masam. PT. Raja Grafindo Persada. Jakarta, 242 p (in Indonesian).

Stevenson FJ. 1994. Humus chemistry. Genesis, composition, reaction. John Wiley and Son Inc. New York. USA. 496 p.

Suriawira. 2003. Mikrobiologi air dan dasar-dasar pengolahan buangan secara biologis. Alumni Bandung. $330 \mathrm{p}$ (in Indonesian).

Tadano $\mathrm{T}$ and $\mathrm{T}$ Yoshida. 1978. Chemical changes in submerged soils and their effect on rice growth. In: Soils and Rice. International Rice Research Institute. Los Banos, The Philippines. pp. 399-420.

Tan KH. 1986. Degradation of soil minerals by organic acid. In: PM Huang and M Schnitzer (eds). Interactions of Soil Minerals with Natural Organics and Microbes. SSSA Special Publication Number 17. Soil Science Society of America, Inc. Madison, Wisconsin, USA, pp. 1-25.

Tan KH. 2003. Humic Mater in the Soil and the Environment: principles and Controversies. Mercel Dekker, Inc. New York. USA. 359p.

White P and MR Broadley. 2003. Calcium in plants. Ann Bot 92 (4): 487-511. 